\title{
Connexin 43: Key roles in the skin (Review)
}

\author{
XIAO-FEI ZHANG and XIAOFENG CUI \\ Department of Biological Sciences and Biotechnology, School of Chemistry, Chemical Engineering \\ and Life Sciences, Wuhan University of Technology, Wuhan, Hubei 430070, P.R. China
}

Received November 21, 2016; Accepted March 17, 2017

DOI: $10.3892 /$ br.2017.903

\begin{abstract}
Gap junctions are tightly packed intercellular channels that serve a common purpose of allowing the intercellular exchange of small metabolites, second messengers and electrical signals. Connexins (Cxs) are gap junction proteins. Currently, 20 and 21 members of Cxs have been characterized in mice and humans, respectively. Connexin 43 (Cx43) is the most ubiquitously expressed type of $\mathrm{Cx}$ in the skin. It is produced by various different types of skin cell, such as keratinocytes, fibroblasts, endothelial and basal cells, melanocytes and dermal papilla cells. At present, more evidence indicates that $\mathrm{Cx} 43$ has an important role in skin repair and skin tumor development, as well as in skin cell invasion and metastasis. In this review, current knowledge regarding the regulation and function of $\mathrm{Cx} 43$ is summarized and the therapeutic potential of regulating $\mathrm{Cx} 43$ activity is discussed.
\end{abstract}

\section{Contents}

1. Introduction

2. Regulation of $\mathrm{Cx} 43$

3. Implications of $\mathrm{Cx} 43$ in skin systems

4. Conclusion

\section{Introduction}

The skin forms a protective barrier between the internal organs and the environment by preventing invasion of pathogens, and fending off chemicals and physical assaults, as well as preventing the unregulated loss of water and solutes $(1,2)$. Skin is arranged into three layers, including the epidermis, dermis and hypodermis (from top to bottom). Cutaneous blood vessels and nerve endings are presented in the dermis and

Correspondence to: Professor Xiaofeng Cui, Department of Biological Sciences and Biotechnology, School of Chemistry, Chemical Engineering and Life Sciences, Wuhan University of Technology, 122 Luoshi Road, Wuhan, Hubei 430070, P.R. China E-mail: xfcui@whut.edu.cn

Key words: gap junction, connexin 43, wound healing, skin diseases, mimetic peptides hypodermis, while the epidermis is avascular with no neural tissue. Therefore, the cell-to-cell communications mediated by GJs provide a crucial mechanism for the integrity of the epidermal barrier and dermal supports (3).

GJ channels formed from Cxs are the predominant intracellular connections that regulate cell permeability and polarity. To date, $21 \mathrm{Cxs}$ have been identified in humans and $20 \mathrm{Cxs}$ in mice $(4,5)$. Cxs are named according to their respective molecular weight, such as Cx26, Cx31, Cx43 and Cx57. The structure differences between them lie in the cytoplasmic loop and carboxyl $(\mathrm{C})$ terminal region. The $\mathrm{Cx}$ subunit contains four hydrophobic transmembrane domains, comprising two extracellular loops, one cytoplasmic loop and one cytoplasmic $\mathrm{N}$-terminal, as well as a C-terminal region. When functioning, six Cx subunits form a hemichannel in the plasma membrane that dock to another hemichannel in the plasma membrane of an adjacent cell to assemble a complete GJ channel (4). These channels allow the exchange and diffusion of various compounds up to a molecular mass of 1,000 Da, for example metabolites, ions, second messengers, water and electrical impulses $(6,7)$. The half-life of Cxs is relatively short, ranging from 1.5 to $5 \mathrm{~h}$ in the majority of tissue and cell types $(8,9)$. However, the mechanism of the balance between Cx synthesis and degradation remains elusive. Abnormal $\mathrm{Cx}$ expression has been reported to be associated with dysregulated cell proliferation, migration and wound healing rates (10).

There are $10 \mathrm{Cxs}$ in human skin, including Cx43, Cx45, Cx40, Cx31, Cx26, Cx32, Cx30, Cx30.3, Cx41.8 and Cx39.3. Cxs display distinct function in the epidermis and dermis with overlapping expression (11). Among these $10 \mathrm{Cxs}, \mathrm{Cx} 43$ is the most ubiquitously expressed in the skin. It is produced by various different types of skin cell, such as keratinocytes, fibroblasts, endothelial and basal cells, melanocytes and dermal papilla cells $(11,12)$.

\section{Regulation of $\mathrm{Cx} 43$}

Cx43 is encoded by gap junction $\alpha 1$ gene (GJAI; MIMno. 121014). The normal expression (10), proper location (13) and accurate connection with other Cxs $(14,15)$ are crucial for its function.

Cx43 expression is regulated at the transcriptional and post-transcriptional levels. One activator protein-1 (AP-1) and two Sp1 transcription factor (SP1) binding sites exist in the 5'-flanking promoter of Cx43 (16). Activated protein kinase C (PKC) and estrogen induce Cx43 transcription through AP-1 and SP1 sites $(16,17)$. Wnt signaling and protease-activated 
receptor-1 (PAR-1) also increase the transcription level of Cx43 (18). Post-transcriptional regulation of Cx43 predominantly relies on its $\mathrm{C}$-terminal region, which contains multiple phosphorylation sites and acts as the functional domain of Cx43. Tumor growth promoting factors, protein kinase and inflammatory mediators, such as PKC (19), mitogen activated protein kinase (20), Src kinase (21), casein kinase 1 (22) and PKA (23), may modulate phosphorylation of Cx43 through serine/tyrosine residues at the C-terminus and subsequently regulate subcellular localization of $\mathrm{Cx} 43$ and GJ formation. However, the effect of phosphorylation of Cx43 on GJ intracellular communication remains uncertain. The ubiquitin (24) and small ubiquitin-related modifier (25) system are important in post-transcriptional regulation of $\mathrm{Cx} 43$ GJs. In addition to post-transcriptional modifications, $\mathrm{Cx} 43$ interacts with a range of cytoskeleton proteins, including zonula occludens-1 (ZO-1), $\mathrm{ZO}-2$, and $\alpha$ - and $\beta$-tubulin, to regulate cell adhesion and migration (26-28).

\section{Implications of $\mathrm{Cx} 43$ in skin system}

Increasing evidence indicates that $\mathrm{Cx} 43$ directly affects the proliferation and migration of keratinocytes and fibroblasts (29). Cx43 also participates in wound healing (30), hyperkeratosis (31) and tumor development of skin $(32,33)$.

Cx43 in cutaneous wound healing. Normal skin regenerates after wounding or damaging. Wound healing is a complicated physiological process in which different types of cell, containing various growth factors and chemokines, are involved $(34,35)$. There are four steps in the wound healing process: Hemostasis, inflammation, migration and proliferation, and remodeling $(34,36)$. During wound healing, the expression of $\mathrm{Cx} 43$ varies and influences cell behaviors.

Numerous factors may regulate the expression levels of Cx43 during repair processes (Fig. 1). Subsequent to wounding, a high concentration of cyclic adenosine monophosphate at the wound site induces a reduction in $\mathrm{Cx} 43$ expression levels and other junction proteins at the plasma membrane, which subsequently destructs the cell junction and causes cytoskeleton remodeling (30). The activated AKT phosphorylates Cx43 at S373 and limits its interaction with ZO-1, potentially leading to activation and migration of keratinocytes in the skin (37).

The expression level of $\mathrm{Cx} 43$ changes dynamically during the wound healing process. On days 1 and 2 subsequent to injury, the mRNA and protein expression levels of $\mathrm{Cx} 43$ were significantly decreased at the wound edge, and readjusted to normal levels (like those in non-injured skin) from day 3 onwards in mice (10). By contrast, the level of Cx43 expression remains at a low level throughout the entire healing process in humans (29). Cx43 reduction has been shown to be associated with: i) Remodeling of the extracellular matrix (ECM) (38); ii) proliferation and migration of keratinocytes and fibroblasts $(10,39,40)$; and iii) regulation of inflammatory responses through certain cytokines, chemokines or growth factors $(38,40)$. Transient knockdown or artificial deficiency of $\mathrm{Cx} 43$ induces the proliferation and migration of keratinocytes and dermal fibroblasts, and enhances ECM production by upregulating collagen type I, collagen type III, matrix metalloproteinase-2 and transforming growth factor (TGF)- $\beta 1$ (38). Additionally, Cx43 knockdown may decrease the expression levels of chemokine (C-C motif) ligand 2 and tumor necrosis factor (TNF) $\alpha$, and elevate the expression levels of TGF- $\beta 1$ and collagen $\alpha 1$, which affects the extravasations of neutrophils and macrophages involved in the wound healing process (40). Furthermore, the angiogenic potential of endothelial cells would be impaired following Cx43 knockdown $(41,42)$. Although the role of $\mathrm{Cx} 43$ reduction in wound healing has been widely accepted, the underlying mechanism and signaling pathway involved in its function require further investigation to provide a solid theoretical basis for its clinical application.

Cx43 is crucial in chronic wound healing. Chronic wounds, such as diabetic foot ulcers, pressure ulcers, and venous leg ulcers are an increasing issue worldwide (43). Diabetic ulcers, the most common diabetic complication, represent a major concern for patients and doctors with regard to quality of life and economics (44). Clinical and experimental evidence suggests that chronic wounds do not follow an orderly progression of wound healing (35). In the case of diabetic ulcers, abnormal expression of $\mathrm{Cx} 43$ was reported (45). As mentioned above, the $\mathrm{Cx} 43$ expression level is decreased at the wound borders during acute injury of normal human skin. By contrast, its expression level elevates by $\sim 10$-fold in human chronic diabetic foot ulcers at the wound edge (46). It was reported that the high glucose level of diabetic cells induces Cx43 expression, and subsequently represses filopodial extensions and fibroblast migration rates (46). However, Vinnik et al (47) observed a minor increase of $\mathrm{Cx} 43$ expression at the wound borders in patients with diabetes mellitus type II. In the study, the $\mathrm{Cx} 43$ expression levels at the wound edge increased by $\sim 1.9$ times following ozone therapy; however, the action mechanism of $\mathrm{Cx} 43$ in this case remains to be elucidated (47). A finding by Mendoza-Naranjo et al (48) that is consistent with the above-mentioned observations demonstrated an increased expression level of $\mathrm{Cx} 43$ in venous leg ulcers, and increased healing rates following $\mathrm{Cx} 43$ shRNA treatment (48).

The role of $\mathrm{Cx} 43$ is not simply to form GJ channels, but also to stabilize a series of proteins, such as N-cadherin and ZO-1, which are required for cell-to-cell adhesion and cell migration $(45,46,48)$, which further illustrates that the sustained inhibition of Cx43 may be efficient for rapid or chronic wound healing.

Cx43 in keratoderma. Cx43 is tightly associated with keratinocyte behaviors. The human $\mathrm{Cx} 43$ gene, or GJA1, is located at human chromosome 6q22-q23 within the candidate region for the oculodentodigital dysplasia (ODDD) locus. A Cx43 mutation directly causes the pleiotropic phenotype of ODDD (49). It is proposed that the gene mutations (c.412G $>$ A/p.Gly138Ser) (50) and deletions (dinucleotide deletion 780_781delTG) (51) causing truncation of the Cx43 C-terminus are necessary and sufficient for palmoplantar keratosis (PPK) development in ODDD patients. More recently, other mutations of $\mathrm{Cx} 43$ have been observed in various types of rare, inherited skin disorder characterized by keratoderma or hypokeratosis with other severe symptoms, including a heterozygous mutation (c.23G $>\mathrm{T}$ [p.Gly8Val]) of GJAl in a family with keratoderma-hypotrichosis-leukonychia totalis syndrome (31) and de novo missense mutations (A44V 


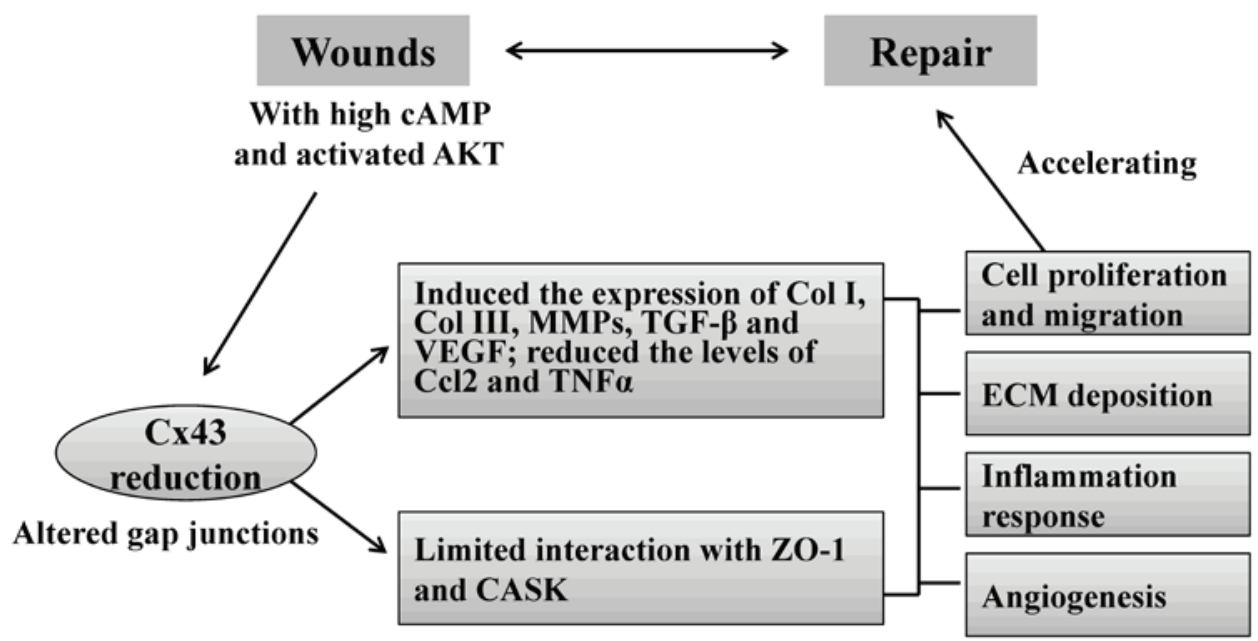

Figure 1. Schematic of the regulation and function of $\mathrm{Cx} 43$ in acute skin injury. Elevated cAMP and pAKT at wound edges alter the expression and phosphorylation levels of Cx43. By mediating the upregulation of Col I, Col III, MMP2, TGF- $\beta 1$ and VEGF, and the downregulation of Cc12 and TNF $\alpha, \mathrm{Cx} 43$ participates in the important wound healing processes, including ECM remodeling, epidermal/dermal cell proliferation and migration, inflammation response and angiogenesis. In addition, dysphosphorylation of $\mathrm{Cx} 43$ affects its interaction with other proteins, such as CASK and ZO-1, and subsequently modulates cell permeability and migration. Overall, Cx43 integrates multiple pathogenic signals to regulate wound healing. Cx43, connexin 43; cAMP, cyclic adenosine monophosphate; pAKT, phosphorylated AKT; Col, collagen; MMP2, matrix metalloproteinase-2; TGF-1, transforming growth factor; VEGF, vascular endothelial growth factor; $\mathrm{Ccl}$ 2, chemokine (C-C motif) ligand 2; TNFo, tumor necrosis factor; $\mathrm{ECM}$, extracellular matrix; CASK, calcium/calmodulin-dependent serine protein kinase; ZO-1, zonula occludens-1.

and E227D) of GJA1 in erythrokeratodermia variabilis et progressiva (52). Mechanistically, GJA1 mutations lead to disruption of $\mathrm{Cx} 43$ membrane localization and aggregation in the Golgi, resulting in excessive opening of hemichannels and cytoplasmic $\mathrm{Ca}^{2+}$ overload, and subsequent keratinocyte apoptosis and hyperkeratosis.

In addition to the above-mentioned mutations, Cx43 participates in epidermal keratinization by interacting with other members of the Cx family. For example, Cx26 mutations, G12R/N14Y or H73R/S183F, directly caused keratitis-ichthyosis-deafness and PPK syndrome, respectively. During these syndromes, $\mathrm{Cx} 26$ mutants may interact with Cx43 more efficiently and exacerbate Cx43 hemichannel activity, thus increasing cell membrane permeability and resulting in ATP release and $\mathrm{Ca}^{2+}$ overload $(14,15)$. These studies further demonstrate the important role of $\mathrm{Cx} 43$ in genetic skin disorders.

Cx43 in melanoma and non-melanoma skin cancer. $\mathrm{Cx} 43$ is closely associated with tumor initiation and development. In skin cancer, $\mathrm{Cx} 43$ is overexpressed in malignant melanomas when compared with the normal and benign nevi $(32,33)$. The upregulation of $\mathrm{Cx} 43$ was associated with an enhanced cell adhesion and invasion of malignant tumor cells $(53,54)$. By acting as a downstream effecter of PAR-1, Cx43 also mediates melanoma metastasis and intracellular communication between the tumor microenvironment and the metastatic tumor cells (46). The roles of Cx43 in melanoma implicate it as an oncogene; however, various independent groups obtained opposing results. Schiffner et al (55) identified Cx43 as a downstream target of nuclear RNA-binding protein p54 ${ }^{\text {nrb }}$. Cx43 knockdown mediated by p54 ${ }^{\text {nrb }}$ promotes cell proliferation and migration in human melanoma cell lines. In mouse melanoma cell lines, $\mathrm{Cx} 43$ reduction induced the expression of vascular endothelial growth factor and tumor angiogenesis (56). Similarly, in human melanoma cell lines, Cx43 overexpression reduced melanoma growth and metastasis, and increased TNF $\alpha$-induced cell apoptosis (57). These controversial results may be due to differences between cell lines, experimental conditions and test points in the studies.

Basal cell carcinoma (BCC) and squamous cell carcinoma (SCC) are the major subtypes of non-melanoma skin cancer (58). Stelkovics et al (59) observed a higher expression level of Cx43 in BCC than that in SCC, indicating that $\mathrm{Cx} 43$ prevented metastatic invasion of BCC (59). In a previous study, immunofluorescence and immunoelectron microscopy were used, and the expression level of $\mathrm{Cx} 43$ was relatively low in the basal layer of human normal skin; but $\mathrm{Cx} 43$ was not detectable in $\mathrm{BCC}$ or SCC, which consequently led to a small number of GJs in BCC and SCC (60). However, the underlying mechanisms of Cx43 function in melanoma and non-melanoma skin cancers remain poorly understood and require further study and discussion.

Cx43 in skin development. Cx43 contributes to epidermal and follicular morphogenesis. During human fetal epidermal development, $\mathrm{Cx} 43$ is expressed at the later stages (88 days) of estimated gestational age (61). In rat and mouse skin, Cx43 is expressed in all of the epidermal layers in the early phase of development $(62,63)$, and is detected in hair follicles and the arrector pili muscles $(12,64)$. The role and underlying mechanism of $\mathrm{Cx} 43$ in epidermal development remains largely unknown. During mouse ovarian folliculogenesis, Cx43-mediated GJs are required for coupling between granulose cells and continued follicular growth (65). In addition, Cx43 evolves in skin cell differentiation. Dyce et al (66) compared stem cells from the skin of wild-type and Cx43 knockout newborn mice. The authors found reduced cell migration rates and decreased expression levels of the pluripotency markers, octamer-binding transcription factor 4 and Nanog in Cx43-deficient stem cells, indicating the role of Cx43 


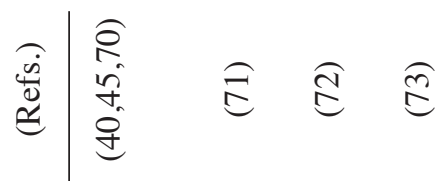

$\widehat{I}$

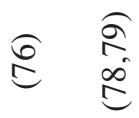

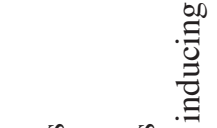

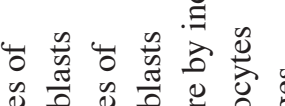

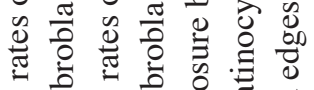

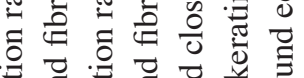

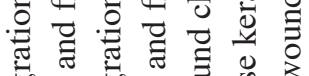

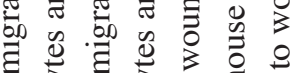

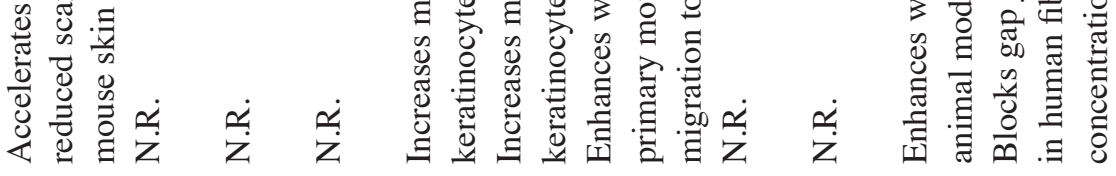

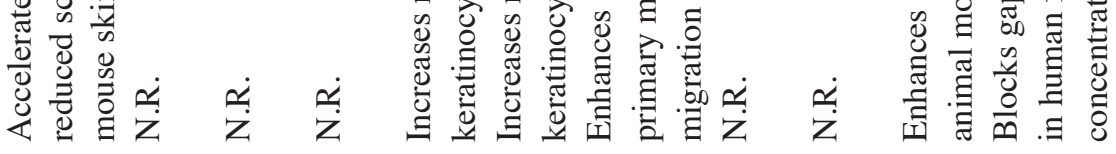

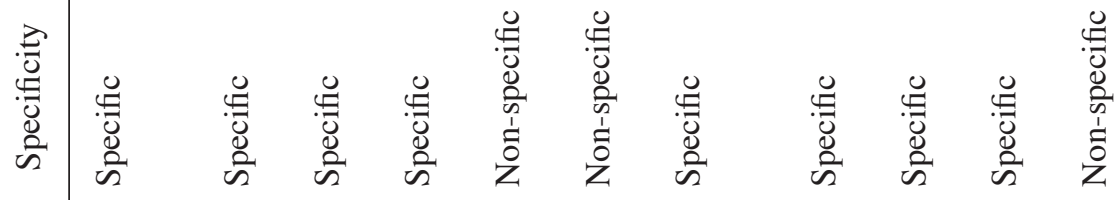

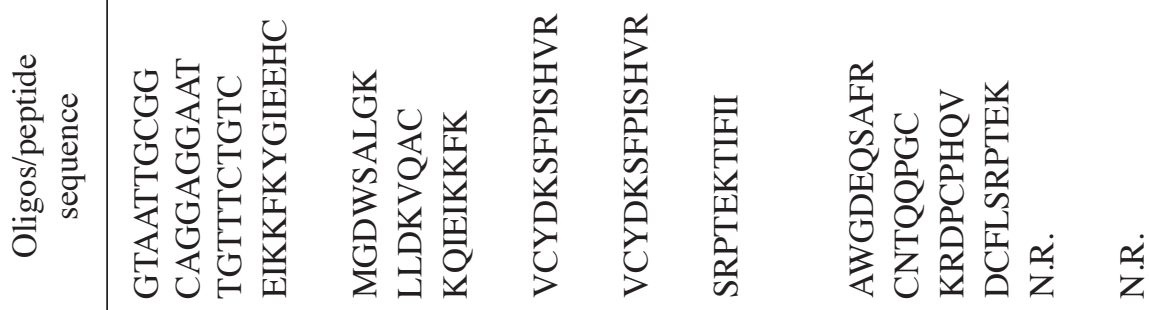

సี.

응

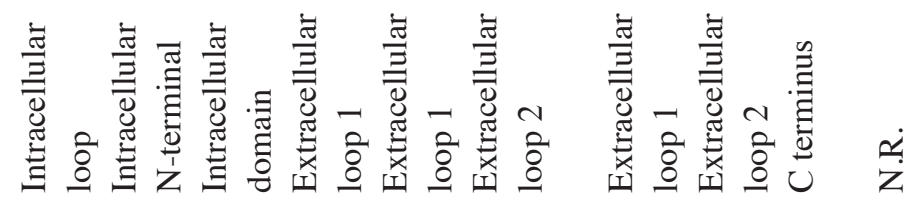

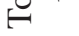

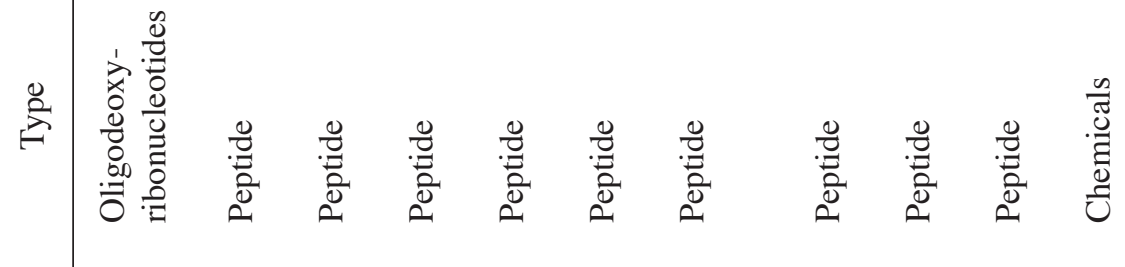

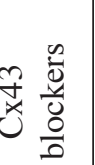

$\frac{0}{0}$

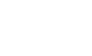

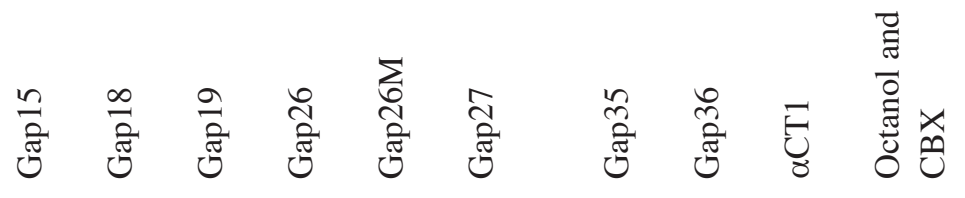


in maintaining the multipotency of skin stem cells (66). The results are partially consistent with a previous study, in which the expression level of $\mathrm{Cx} 43$ was maintained at a higher level in an undifferentiated epidermis and markedly decreased in the differentiation of the epidermis (12).

Therapeutic modalities based on regulating Cx43 activity. Increasing evidence has identified a positive correlation between $\mathrm{Cx} 43$ inhibition and wound healing rates $(67,68)$. Furthermore, $\mathrm{Cx} 43$ reduction relieves inflammation in chronic wounds (69). Currently, drug design and development based on Cx43 is an important research area. There are two methods for artificially downregulating $\mathrm{Cx} 43$, which involve antisense oligodeoxyribonucleotides (ODNs) and mimetic peptides (Table I). Antisense ODNs may have accelerated wound healing and reduced scar formation in normal mouse skin and diabetic rat skin $(40,45,70)$. Cx43 mimetic peptides include Gap 15 (71), Gap 18 (72), Gap 19 (73), Gap 26 (74), Gap 26M (Gap26 modified with acylation to improve solubility and stability) (74), Gap 27 (74), Gap 35 (72) and Gap36 (72). Among these, the most evaluated peptides in skin cells are Gap26, Gap26M and Gap27. Gap26 and Gap26M directly interacted with amino acids 63-75 of the extracellular loop 1 of $\mathrm{Cx} 43$ (VCYDKSFPISHVR); Gap27 mimicked amino acids 204-214 on the extracellular loop 2 of Cx43 (SRPTEKTIFII) (74). Gap26 and Gap26M are non-Cx43 specific, whereas Gap27 is Cx43-selective (74). Various studies have demonstrated that peptide treatment significantly increases the migration rates of keratinocytes and fibroblasts to wound edges $(74,75)$. In addition to the above-mentioned peptides, Ongstad et al (76) designed a cell-permanent $\alpha$-connexin carboxyl-terminal ( $\alpha \mathrm{CT} 1)$ peptide based on the $\mathrm{C}$-terminus of $\mathrm{Cx} 43$. The peptides encapsulated in pluronic F127 thermogel and methylcellulose demonstrated a significant accelerating effect on wound healing in pre-clinical animal models of the skin and heart. An external application of $\alpha \mathrm{CT} 1$ on wound healing is now set to proceed into phase I and II clinical trials (76). Gap19 is currently applied for the treatment of myocardial ischemia/reperfusion injury and, to the best of our knowledge, there are no reports regarding its application in wound healing (73). Other peptides, including Gap15, Gap18, Gap35 and Gap36 were reported as Cx43 selective blockers; however, the function of these in cutaneous systems remain elusive $(71,72)$. Various chemicals, including octanol and $18 \beta$-glycyrrhetinic acid and its water-soluble derivative, carbenoxolone, block intercellular junctional communication by targeting Cxs (77-79).

Notably, primary diabetic cells exhibited less susceptibility to $\mathrm{Cx} 43$ inhibitors $(80,81)$; therefore, the clinical application of administering $\mathrm{Cx} 43$ peptides for the treatment of chronic diabetic wounds requires further critical consideration. As the mode-of-action of Cxs is not unique, selective downregulation of one $\mathrm{Cx}$ rather than using broad-spectrum inhibitors would be preferable. Furthermore, the functional mechanism and effects of $\mathrm{Cx} 43$ mimetic peptides on other tissues have yet to be determined.

\section{Conclusion}

Recent studies on Cx43 in the skin clearly demonstrate that Cx43 is important in human skin biology and pathology. The expression level and activity of $\mathrm{Cx} 43$ are strictly regulated in certain situations. Downregulation of $\mathrm{Cx} 43$ following tissue injury significantly reduces ECM deposition, inflammation response and scar formation, and accelerates wound healing rates. Currently, $\mathrm{Cx} 43$ expression levels and functions have been presented in skin injury, skeletal muscle regeneration (82), ischemia/reperfusion injury (83) and cornea repair (84). The $\mathrm{Cx}$-associated compounds are in development and indicate promising therapeutic opportunities in preclinical evaluation (85). Non-toxic Cx43 specific inhibitors may also be effective for the treatment of wounds, skin cancer or other skin associated disorders. Therefore, it is considered urgent to investigate the underlying mechanisms and clinical potential of $\mathrm{Cx} 43$ in the skin.

\section{Acknowledgements}

The present study was supported by the Fundamental Research Funds for the Central Universities (grant no. 2015IB004) and the China Postdoctoral Science Foundation (grant no. 2015M582291).

\section{References}

1. Proksch E, Brandner JM and Jensen JM: The skin: An indispensable barrier. Exp Dermatol 17: 1063-1072, 2008.

2. Kanitakis J: Anatomy, histology and immunohistochemistry of normal human skin. Eur J Dermatol 12: 390-399; quiz 400-401, 2002.

3. Martin PE, Easton JA, Hodgins MB and Wright CS: Connexins: Sensors of epidermal integrity that are therapeutic targets. FEBS Lett 588: 1304-1314, 2014.

4. Söhl G and Willecke K: Gap junctions and the connexin protein family. Cardiovasc Res 62: 228-232, 2004.

5. Söhl G and Willecke K: An update on connexin genes and their nomenclature in mouse and man. Cell Commun Adhes 10: 173-180, 2003.

6. Kumar NM and Gilula NB: The gap junction communication channel. Cell 84: 381-388, 1996.

7. Alexander DB and Goldberg GS: Transfer of biologically important molecules between cells through gap junction channels. Curr Med Chem 10: 2045-2058, 2003.

8. Hervé JC, Derangeon M, Bahbouhi B, Mesnil M and Sarrouilhe D: The connexin turnover, an important modulating factor of the level of cell-to-cell junctional communication: Comparison with other integral membrane proteins. J Membr Biol 217: 21-33, 2007.

9. Berthoud VM, Minogue PJ, Laing JG and Beyer EC: Pathways for degradation of connexins and gap junctions. Cardiovasc Res 62: 256-267, 2004.

10. Kretz M, Euwens C, Hombach S, Eckardt D, Teubner B, Traub O, Willecke $\mathrm{K}$ and Ott T: Altered connexin expression and wound healing in the epidermis of connexin-deficient mice. J Cell Sci 116: 3443-3452, 2003.

11. Di WL, Rugg EL, Leigh IM and Kelsell DP: Multiple epidermal connexins are expressed in different keratinocyte subpopulations including connexin 31. J Invest Dermatol 117: 958-964, 2001.

12. Risek B, Klier FG and Gilula NB: Multiple gap junction genes are utilized during rat skin and hair development. Development 116: 639-651, 1992 .

13. Wu M, Moh MC and Schwarz H: HepaCAM associates with connexin 43 and enhances its localization in cellular junctions. Sci Rep 6: 36218, 2016.

14. Garcia IE, Maripillán J, Jara O, Ceriani R, Palacios-Muñoz A, Ramachandran J, Olivero P, Perez-Acle T, González C, Sáez JC, et al: Keratitis-ichthyosis-deafness syndrome-associated Cx26 mutants produce nonfunctional gap junctions but hyperactive hemichannels when co-expressed with wild type $\mathrm{Cx} 43$. J Invest Dermatol 135: 1338-1347, 2015.

15. Shuja Z, Li L, Gupta S, Mese G and White TW: Connexin26 mutations causing palmoplantar keratoderma and deafness interact with connexin43, modifying gap junction and hemichannel properties. J Invest Dermatol 136: 225-235, 2016. 
16. Geimonen E, Jiang W, Ali M, Fishman GI, Garfield RE and Andersen J: Activation of protein kinase $\mathrm{C}$ in human uterine smooth muscle induces connexin-43 gene transcription through an AP-1 site in the promoter sequence. J Biol Chem 271: 23667-23674, 1996.

17. Geimonen E, Boylston E, Royek A and Andersen J: Elevated connexin-43 expression in term human myometrium correlates with elevated c-Jun expression and is independent of myometrial estrogen receptors. J Clin Endocrinol Metab 83: 1177-1185, 1998.

18. van der Heyden MA, Rook MB, Hermans MM, Rijksen G, Boonstra J, Defize LH and Destrée OH: Identification of connexin43 as a functional target for Wnt signalling. J Cell Sci 111: 1741-1749, 1998

19. Bao X, Lee SC, Reuss L and Altenberg GA: Change in permeant size selectivity by phosphorylation of connexin 43 gap-junctional hemichannels by PKC. Proc Natl Acad Sci USA 104: 4919-4924, 2007.

20. Riquelme MA, Burra S, Kar R, Lampe PD and Jiang JX: Mitogen-activated protein kinase (MAPK) activated by prostaglandin E2 phosphorylates connexin 43 and closes osteocytic hemichannels in response to continuous flow shear stress. J Biol Chem 290: 28321-28328, 2015 .

21. Pahujaa M, Anikin M and Goldberg GS: Phosphorylation of connexin43 induced by Src: Regulation of gap junctional communication between transformed cells. Exp Cell Res 313 4083-4090, 2007.

22. Cooper CD and Lampe PD: Casein kinase 1 regulates connexin- 43 gap junction assembly. J Biol Chem 277: 44962-44968, 2002.

23. TenBroek EM, Lampe PD, Solan JL, Reynhout JK and Johnson RG: Ser364 of connexin43 and the upregulation of gap junction assembly by cAMP. J Cell Biol 155: 1307-1318, 2001.

24. Kjenseth A, Fykerud T, Rivedal E and Leithe E: Regulation of gap junction intercellular communication by the ubiquitin system. Cell Signal 22: 1267-1273, 2010.

25. Kjenseth A, Fykerud TA, Sirnes S, Bruun J, Yohannes Z, Kolberg M, Omori Y, Rivedal E and Leithe E: The gap junction channel protein connexin 43 is covalently modified and regulated by SUMOylation. J Biol Chem 287: 15851-15861, 2012.

26. Giepmans BN, Verlaan I and Moolenaar WH: Connexin-43 interactions with ZO-1 and alpha- and beta-tubulin. Cell Commun Adhes 8: 219-223, 2001.

27. Giepmans BN, Verlaan I, Hengeveld T, Janssen H, Calafat J, Falk MM and Moolenaar WH: Gap junction protein connexin-43 interacts directly with microtubules. Curr Biol 11: 1364-1368, 2001.

28. Shaw RM, Fay AJ, Puthenveedu MA, von Zastrow M, Jan YN and Jan LY: Microtubule plus-end-tracking proteins target gap junctions directly from the cell interior to adherens junctions. Cell 128: 547-560, 2007.

29. Plante I, Stewart MK, Barr K, Allan AL and Laird DW: Cx43 suppresses mammary tumor metastasis to the lung in a $\mathrm{Cx} 43$ mutant mouse model of human disease. Oncogene 30: 1681-1692, 2011.

30. Kim MO, Ryu JM, Suh HN, Park SH, Oh YM, Lee SH and Han HJ: cAMP promotes cell migration through cell junctional complex dynamics and actin cytoskeleton remodeling: Implications in skin wound healing. Stem Cells Dev 24 2513-2524, 2015.

31. Wang H, Cao X, Lin Z, Lee M, Jia X, Ren Y, Dai L, Guan L, Zhang J, Lin X, et al: Exome sequencing reveals mutation in GJA1 as a cause of keratoderma-hypotrichosis-leukonychia totalis syndrome. Hum Mol Genet 24: 243-250, 2015.

32. Sargen MR, Gormley RH, Pasha TL, Yum S, Acs G, Xu X and Zhang PJ: Melanocytic tumors express connexin 43 but not 26: Immunohistochemical analysis with potential significance in melanocytic oncogenesis. Am J Dermatopathol 35: 813-817, 2013.

33. Rezze GG, Fregnani JH, Duprat J and Landman G: Cell adhesion and communication proteins are differentially expressed in melanoma progression model. Hum Pathol 42: 409-418, 2011.

34. Shaw TJ and Martin P: Wound repair at a glance. J Cell Sci 122: 3209-3213, 2009

35. Falanga V: Wound healing and its impairment in the diabetic foot. Lancet 366: 1736-1743, 2005

36. Janis JE, Kwon RK and Lalonde DH: A practical guide to wound healing. Plast Reconstr Surg 125: 230e-244e, 2010.

37. Dunn CA and Lampe PD: Injury-triggered Akt phosphorylation of Cx43: A ZO-1-driven molecular switch that regulates gap junction size. J Cell Sci 127: 455-464, 2014.
38. Cogliati B, Vinken M, Silva TC, Araújo CM, Aloia TP, Chaible LM, Mori CM and Dagli ML: Connexin 43 deficiency accelerates skin wound healing and extracellular matrix remodeling in mice. J Dermatol Sci 79: 50-56, 2015.

39. Ghatnekar GS, O'Quinn MP, Jourdan LJ, Gurjarpadhye AA Draughn RL and Gourdie RG: Connexin43 carboxyl-terminal peptides reduce scar progenitor and promote regenerative healing following skin wounding. Regen Med 4: 205-223, 2009.

40. Mori R, Power KT, Wang CM, Martin P and Becker DL: Acute downregulation of connexin43 at wound sites leads to a reduced inflammatory response, enhanced keratinocyte proliferation and wound fibroblast migration. J Cell Sci 119: 5193-5203, 2006.

41. Wang HH, Su CH, Wu YJ, Li JY, Tseng YM, Lin YC, Hsieh CL, Tsai CH and Yeh HI: Reduction of connexin43 in human endothelial progenitor cells impairs the angiogenic potential. Angiogenesis 16: 553-560, 2013.

42. Gartner C, Ziegelhöffer B, Kostelka M, Stepan H, Mohr FW and Dhein S: Knock-down of endothelial connexins impairs angiogenesis. Pharmacol Res 65: 347-357, 2012.

43. Gottrup F: A specialized wound-healing center concept: Importance of a multidisciplinary department structure and surgical treatment facilities in the treatment of chronic wounds. Am J Surg 187 (Suppl 5A): 38S-43S, 2004.

44. Reiber GE, Lipsky BA and Gibbons GW: The burden of diabetic foot ulcers. Am J Surg 176 (Suppl 2A): 5S-10S, 1998.

45. Wang CM, Lincoln J, Cook JE and Becker DL: Abnormal connexin expression underlies delayed wound healing in diabetic skin. Diabetes 56: 2809-2817, 2007.

46. Mendoza-Naranjo A, Cormie P, Serrano AE, Wang CM, Thrasivoulou C, Sutcliffe JE, Gilmartin DJ, Tsui J, Serena TE, Phillips AR and Becker DL: Overexpression of the gap junction protein $\mathrm{Cx} 43$ as found in diabetic foot ulcers can retard fibroblast migration. Cell Biol Int 36: 661-667, 2012.

47. Vinnik IuS, Salmina AB, Tepliakova OV, Drobushevskaia AI Malinovskaia NA, Pozhilenkova EA, Morgun AV and Gitlina AG: Dynamics of local expression of connexin-43 and basic fibroblast growth factor receptors in patients with skin and soft-tissue infections against the background of diabetes mellitus type II. Vestn Khir Im I I Grek 173: 47-52, 2014 (In Russian).

48. Mendoza-Naranjo A, Cormie P, Serrano AE, Hu R, O'Neill S, Wang CM, Thrasivoulou C, Power KT, White A, Serena T, et al: Targeting Cx43 and N-cadherin, which are abnormally upregulated in venous leg ulcers, influences migration, adhesion and activation of Rho GTPases. PLoS One 7: e37374, 2012.

49. Paznekas WA, Boyadjiev SA, Shapiro RE, Daniels O, Wollnik B, Keegan CE, Innis JW, Dinulos MB, Christian C, Hannibal MC and Jabs EW: Connexin 43 (GJA1) mutations cause the pleiotropic phenotype of oculodentodigital dysplasia. Am J Hum Genet 72: 408-418, 2003.

50. Kogame T, Dainichi T, Shimomura Y, Tanioka M, Kabashima K and Miyachi Y: Palmoplantar keratosis in oculodentodigital dysplasia with a GJA1 point mutation out of the C-terminal region of connexin 43. J Dermatol 41: 1095-1097, 2014.

51. van Steensel MA, Spruijt L, van der Burgt I, Bladergroen RS, Vermeer M, Steijlen PM and van Geel M: A 2-bp deletion in the GJA1 gene is associated with oculo-dento-digital dysplasia with palmoplantar keratoderma. Am J Med Genet A 132A: 171-174, 2005.

52. Boyden LM, Craiglow BG, Zhou J, Hu R, Loring EC, Morel KD, Lauren CT, Lifton RP, Bilguvar K; Yale Center for Mendelian Genomics, et al: Dominant de novo mutations in GJA1 cause erythrokeratodermia variabilis et progressiva, without features of oculodentodigital dysplasia. J Invest Dermatol 135: 1540-1547, 2015.

53. Mou YY, Zhao GQ, Lin JY, Zhao J, Lin H, Hu LT, Xu Q, Wang Q and Sun WR: Expression of connexin 43 and E-cadherin in choroidal melanoma. Int J Ophthalmol 4: 156-161, 2011.

54. Lin JH, Takano T, Cotrina ML, Arcuino G, Kang J, Liu S, Gao Q, Jiang L, Li F, Lichtenberg-Frate H, et al: Connexin 43 enhances the adhesivity and mediates the invasion of malignant glioma cells. J Neurosci 22: 4302-4311, 2002.

55. Schiffner S, Zimara N, Schmid R and Bosserhoff AK: p54nrb is a new regulator of progression of malignant melanoma. Carcinogenesis 32: 1176-1182, 2011.

56. Wang WK, Chen MC, Leong HF, Kuo YL, Kuo CY and Lee CH: Connexin 43 suppresses tumor angiogenesis by down-regulation of vascular endothelial growth factor via hypoxic-induced factor-1 $\alpha$. Int J Mol Sci 16: 439-451, 2014 
57. Tittarelli A, Guerrero I, Tempio F, Gleisner MA, Avalos I, Sabanegh S, Ortíz C, Michea L, López MN, Mendoza-Naranjo A and Salazar-Onfray F: Overexpression of connexin 43 reduces melanoma proliferative and metastatic capacity. Br J Cancer 113: $259-267,2015$

58. Lomas A, Leonardi-Bee J and Bath-Hextall F: A systematic review of worldwide incidence of nonmelanoma skin cancer. $\mathrm{Br}$ J Dermatol 166: 1069-1080, 2012.

59. Stelkovics E, Kiszner G, Meggyeshazi N, Korom I, Varga E, Nemeth I, Molnar J and Marczinovits I: Selective in situ protein expression profiles correlate with distinct phenotypes of basal cell carcinoma and squamous cell carcinoma of the skin. Histol Histopathol 28: 941-954, 2013

60. Tada $\mathbf{J}$ and Hashimoto K: Ultrastructural localization of gap junction protein connexin 43 in normal human skin, basal cell carcinoma, and squamous cell carcinoma. J Cutan Pathol 24: 628-635, 1997.

61. Arita K, Akiyama M, Tsuji Y, McMillan JR, Eady RA and Shimizu H: Changes in gap junction distribution and connexin expression pattern during human fetal skin development. J Histochem Cytochem 50: 1493-1500, 2002.

62. Choudhry R, Pitts JD and Hodgins MB: Changing patterns of gap junctional intercellular communication and connexin distribution in mouse epidermis and hair follicles during embryonic development. Dev Dyn 210: 417-430, 1997.

63. Goliger JA and Paul DL: Expression of gap junction proteins Cx26, Cx31.1, Cx37, and Cx43 in developing and mature rat epidermis. Dev Dyn 200: 1-13, 1994.

64. Butterweck A, Elfgang C, Willecke K and Traub O: Differential expression of the gap junction proteins connexin 45,-43, -40, -31, and -26 in mouse skin. Eur J Cell Biol 65: 152-163, 1994.

65. Ackert CL, Gittens JE, O'Brien MJ, Eppig JJ and Kidder GM: Intercellular communication via connexin43 gap junctions is required for ovarian folliculogenesis in the mouse. Dev Biol 233: 258-270, 2001

66. Dyce PW, Li D, Barr KJ and Kidder GM: Connexin43 is required for the maintenance of multipotency in skin-derived stem cells. Stem Cells De 23: 1636-1646, 2014.

67. Lorraine $\mathrm{C}$, Wright CS and Martin PE: Connexin 43 plays diverse roles in co-ordinating cell migration and wound closure events. Biochem Soc Trans 43: 482-488, 2015.

68. Moore K, Ghatnekar G, Gourdie RG and Potts JD: Impact of the controlled release of a connexin 43 peptide on corneal wound closure in an STZ model of type I diabetes. PLoS One 9: e86570, 2014.

69. Gilmartin DJ, Soon A, Thrasivoulou C, Phillips AR, Jayasinghe SN and Becker DL: Sustained release of Cx43 antisense oligodeoxynucleotides from coated collagen scaffolds promotes wound healing. Adv Healthc Mater 5: 1786-1799, 2016.

70. Qiu C, Coutinho P, Frank S, Franke S, Law LY, Martin P, Green CR and Becker DL: Targeting connexin43 expression accelerates the rate of wound repair. Curr Biol 13: 1697-1703, 2003.

71. Boitano S, Dirksen ER and Evans WH: Sequence-specific antibodies to connexins block intercellular calcium signaling through gap junctions. Cell Calcium 23: 1-9, 1998.

72. Oviedo-Orta E, Hoy T and Evans WH: Intercellular communication in the immune system: Differential expression of connexin40 and 43 , and perturbation of gap junction channel functions in peripheral blood and tonsil human lymphocyte subpopulations. Immunology 99: 578-590, 2000.
73. Wang N, De Vuyst E, Ponsaerts R, Boengler K, Palacios-Prado N, Wauman J, Lai CP, De Bock M, Decrock E, Bol M, et al: Selective inhibition of $\mathrm{Cx} 43$ hemichannels by Gap19 and its impact on myocardial ischemia/reperfusion injury. Basic Res Cardiol 108: 309, 2013

74. Wright CS, van Steensel MA, Hodgins MB and Martin PE: Connexin mimetic peptides improve cell migration rates of human epidermal keratinocytes and dermal fibroblasts in vitro. Wound Repair Regen 17: 240-249, 2009.

75. Kandyba EE, Hodgins MB and Martin PE: A murine living skin equivalent amenable to live-cell imaging: Analysis of the roles of connexins in the epidermis. J Invest Dermatol 128: 1039-1049, 2008.

76. Ongstad EL, O'Quinn MP, Ghatnekar GS, Yost MJ and Gourdie RG: A Connexin43 mimetic peptide promotes regenerative healing and improves mechanical properties in skin and heart. Adv Wound Care (New Rochelle) 2: 55-62, 2013.

77. Contreras JE, Sanchez HA, Eugenin EA, Speidel D, Theis M, Willecke K, Bukauskas FF, Bennett MV and Sáez JC: Metabolic inhibition induces opening of unapposed connexin 43 gap junction hemichannels and reduces gap junctional communication in cortical astrocytes in culture. Proc Natl Acad Sci USA 99: 495-500, 2002

78. Goldberg GS, Moreno AP, Bechberger JF, Hearn SS, Shivers RR, MacPhee DJ, Zhang YC and Naus CC: Evidence that disruption of connexon particle arrangements in gap junction plaques is associated with inhibition of gap junctional communication by a glycyrrhetinic acid derivative. Exp Cell Res 222: 48-53, 1996.

79. Davidson JS and Baumgarten IM: Glycyrrhetinic acid derivatives: A novel class of inhibitors of gap-junctional intercellular communication. Structure-activity relationships. J Pharmacol Exp Ther 246: 1104-1107, 1988.

80. Pollok S, Pfeiffer AC, Lobmann R, Wright CS, Moll I, Martin PE and Brandner JM: Connexin 43 mimetic peptide Gap27 reveals potential differences in the role of $\mathrm{Cx} 43$ in wound repair between diabetic and non-diabetic cells. J Cell Mol Med 15: 861-873, 2011.

81. Wright CS, Berends RF, Flint DJ and Martin PE: Cell motility in models of wounded human skin is improved by Gap27 despite raised glucose, insulin and IGFBP-5. Exp Cell Res 319: 390-401, 2013.

82. Ishido $\mathrm{M}$ and Kasuga N: Characteristics of the localization of connexin 43 in satellite cells during skeletal muscle regeneration in vivo. Acta Histochem Cytochem 48: 53-60, 2015.

83. Schulz R, Görge PM, Gorbe A, Ferdinandy P, Lampe PD and Leybaert L: Connexin 43 is an emerging therapeutic target in ischemia/reperfusion injury, cardioprotection and neuroprotection. Pharmacol Ther 153: 90-106, 2015.

84. Elbadawy HM, Mirabelli P, Xeroudaki M, Parekh M, Bertolin M, Breda C, Cagini C, Ponzin D, Lagali N and Ferrari S: Effect of Connexin 43 inhibition by the mimetic peptide Gap27 on corneal wound healing, inflammation and neovascularization. Br J Pharmacol 173: 2880-2893, 2016

85. Becker DL, Phillips AR, Duft BJ, Kim Y and Green CR: Translating connexin biology into therapeutics. Semin Cell Dev Biol 50: 49-58, 2016. 